\title{
RESEARCH PAPERS
}

\section{Current Archaeological Research in Panamá Viejo, Panamá}

\author{
Tomás Mendizábal \\ Institute of Archaeology, UCL
}

\section{Introduction}

In late 1995 the government and private entities formed a pioneer organisation in Panamanian culture resource management, to deal with Panamá's most salient archaeological site, Panamá Viejo. This association, the Patronato Panamá Viejo, was thus commissioned with the investigation and preservation of this 28-hectare site in the centre of modern Panamá City, as well as with keeping the community informed on the progress of the research. It is formed by four partners, the Instituto Nacional de Cultura and the Instituto Nacional de Turismo from the government, and the Kiwanis Club and the Banco del Istmo from the private sector. For the first time, an exclusively Panamanian non-profit organisation would confront this task on a large scale, with a multidisciplinary team of archaeologists, architects, and conservationists, with on-site facilities and laboratories aimed at an in depth study of Panamá's historic and prehistoric past. This organisation is currently conducting extensive archaeological excavations on the site, protecting the stone monuments from further damage from natural and human elements, and trying to inform and educate the public on Panamá Viejo’s importance to the country’s historical and cultural heritage, and to develop it as a valuable tourist attraction.

\section{The Site}

The site constitutes the original Spanish settlement of the town called Panamá, founded in AD 1519, the first European town on the American Pacific coast (Figure 1). It served first as a base for the exploration of Central and South America, and then as a necessary crossing point for the gold and silver coming from the South American mines on their way to Spain. It led a reasonably prosperous life as a trading town and crossroads, until Henry Morgan attacked in 1671, sacking and destroying most of it. The survivors decided to move ten kilometres west to a more protected site and build a new city there. In 1673 the new city was officially founded, and since then, it has gradually grown to the point that today the ruins of "Panamá Viejo (Old Panamá)”, as they are now called, lie at the centre of modern Panamá City.

The site today is roughly $\mathrm{L}$ shaped, with the main Plaza and town centre on the corner of the L, to the south-east (Figure 2). Its limits are, to the south the Bay of Panamá, to the west the Matadero or Algarrobo River, to the east the Gallinero River, and to the north the modern neighbourhood of Panamá Viejo. This modern neighbourhood is standing where the ancient slums of the town stood, as the rich and middle class people lived in and around the centre. The poor whites, Indians, and blacks lived on the outskirts in two slums, Pierdevidas and Malambo, both to the north-west and north respectively of the town. All visible ruins above ground are what have survived of the stone and masonry buildings, which belonged to the Colonial administration, the Church or the very rich. The calculated area of the original site was approximately 70 hectares.

Papers from the Institute of Archaeology 10 (1999): 25-36 


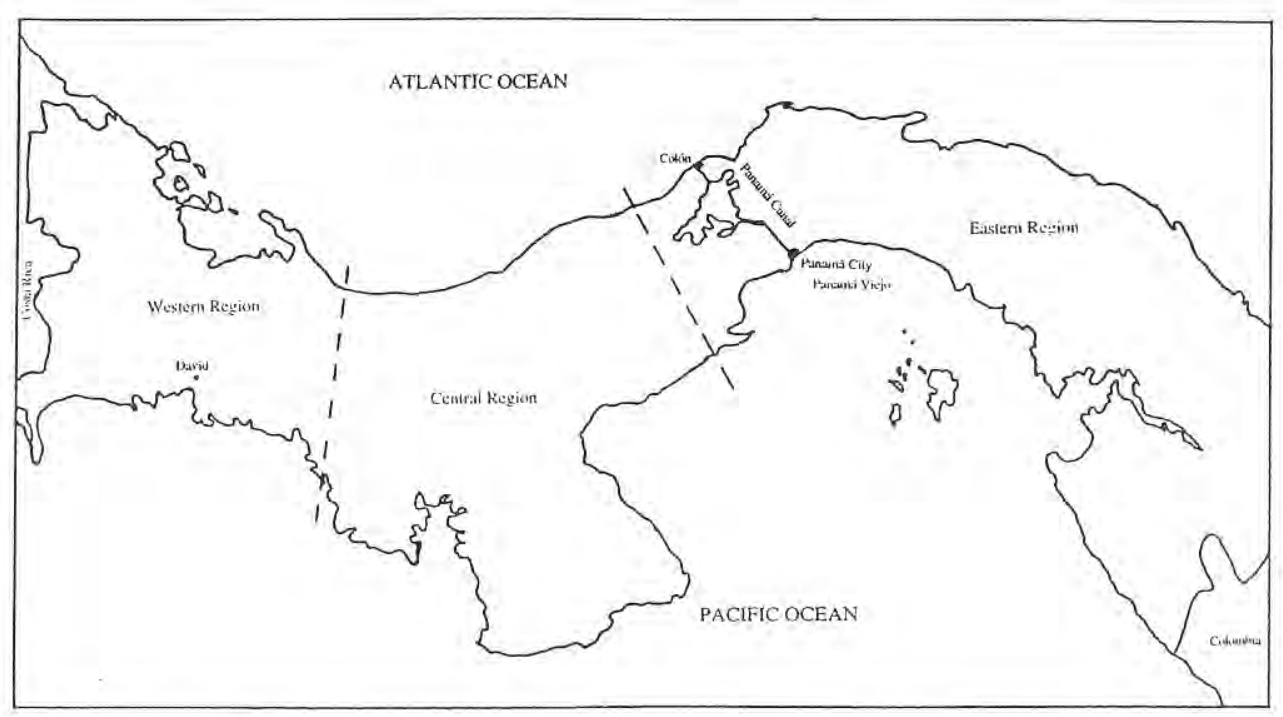

Figure 1 Map of the Republic of Panamá and major archaeological regions (Cooke 1976)

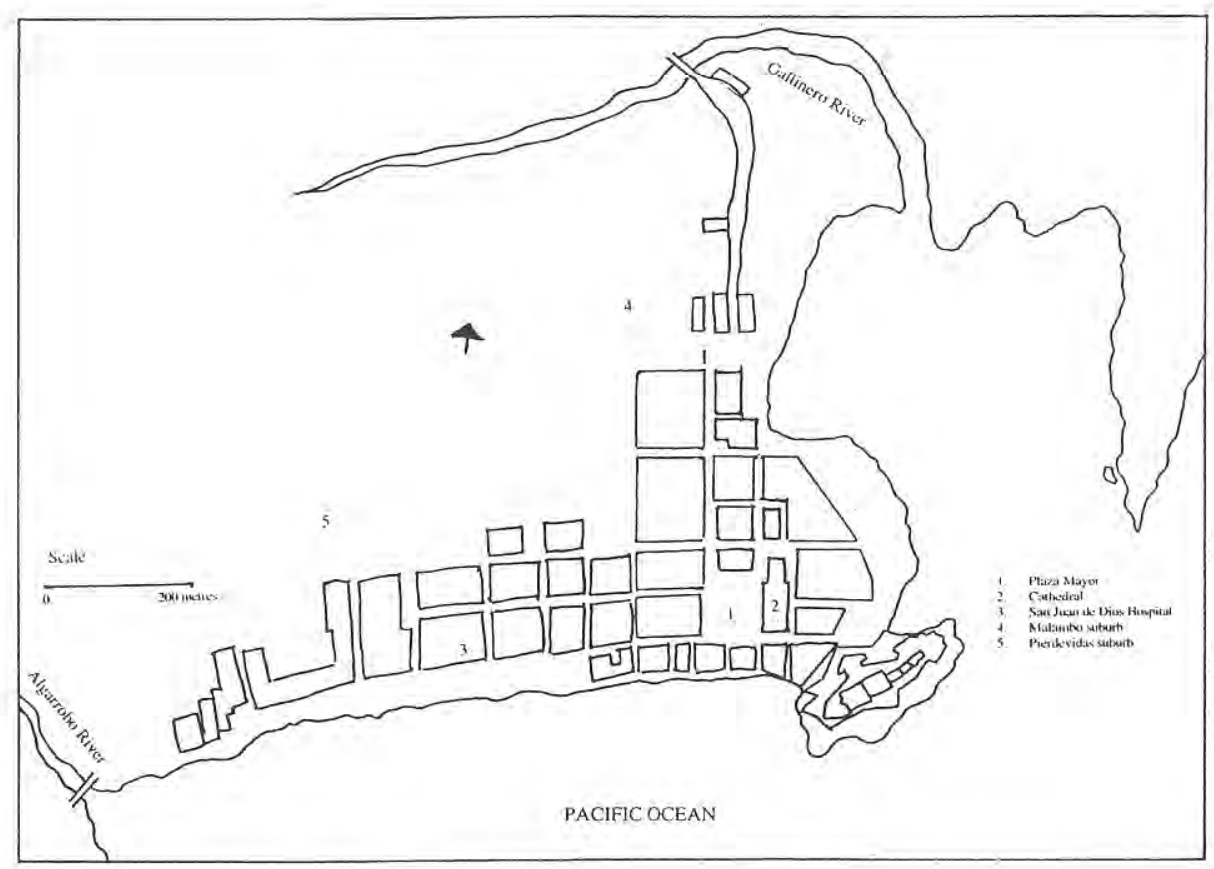

Figure 2 Representation of Panamá Viejo's layout in the Sixteenth Century (from Mena García 1992: 94-95) 
Working in Panamá Viejo presents several advantages. Logistically speaking, its situation in the centre of Panamá City provides easy access to the site. For archaeology, it is particularly advantageous since it is a time capsule: everything relating to the Spanish colony is contained within the 1519-1671 time span. It is a multi-component site for not only do we have the Colonial settlement, but also the earlier Precolumbian village underneath the Spanish ruins. The multivariate nature of the evidence and the sheer size of the site have provided work for a host of specialists, from anthropologists and archaeologists, to restoration architects, physicists, and biologists.

Panamá Viejo has been subject only to sporadic archaeological studies until recently, when the Patronato Panamá Viejo was formed. The current archaeological project's purpose is to uncover and restore the original layout of the Plaza Mayor (Main Square) and its surrounding area, including the buildings around it. Research has brought to light evidence from the Colonial occupation in the $16^{\text {th }}$ and $17^{\text {th }}$ centuries as well as Precolumbian remains. In three field seasons since the beginning of 1996, most of the area around the Square has been excavated. Together with Alvaro Brizuela and Mirta Linero (who joined us in 1998), I have participated in these excavations as Assistant Archaeologist, under the direction of Dr. Beatriz Rovira from the University of Panamá, Project leader. Excavations continue with the present 1999 season.

The Plaza Mayor of Panamá Viejo has suffered many changes since the town's abandonment. In the centuries that followed, the jungle swallowed the ruins, and it was not until the early 1900's that a cleanup attempt took place. In the 1950's, to celebrate the 50th anniversary of Panamanian independence, the government decided to build a commemorative park on the Plaza. The construction of this park resulted in the almost complete disturbance of the Colonial levels with two layers of modern fill, one of sand and one of earth, packed with a mix of Colonial and contemporary artefacts. This activity not only disturbed the Plaza itself, where it presumably erased most of the original occupation levels, but it also affected the Colonial housing area to the west of the Plaza. As these houses showed no above ground remains, the modern architects probably did not think they would be disturbing anything. Thus the houses were covered in sand and earth, the new park covering the whole Plaza and about 25 metres of the block of houses directly to the west. The park was completed by the addition of a surrounding paved street, in the form of a horseshoe. The Patronato's goal, now, is to remove the park, the street, commemorative statues and any other modern features that make reading the original layout impossible to the visitor; it was with this problem in mind that the field season of 1996 began, when exploring the terrain to the west of the Plaza, where in Colonial times a residential area of wooden houses had stood.

\section{Archaeological Fieldwork Seasons}

The 1996 field season was also dedicated to exploring the Cabildo (Town Hall) offices, whose ruins were covered by another ornamental garden, to the east of the Plaza. In 1997, the north side of the Plaza was excavated, this time uncovering the ruins of the Casas Terrín, a stone building that belonged to the Terrín Family in the 17th century. The field season of 1998 consisted of an intensive, systematic survey 
of the Plaza itself, in an effort to determine its original level and whether it had any kind of flooring, as well as to look for and excavate any Precolumbian remains, following the discovery in 1996 of one Precolumbian burial under the floor of one of the houses to the west of the Plaza. After the excavations were carried out, all stone and masonry features exposed were given conservation treatment to protect them from the tropical weather.

All the materials recovered at Panamá Viejo are taken to on-site laboratories. Most go directly to the Archaeology laboratory for cleaning and preliminary sorting. Any delicate or poorly preserved artefacts (such as skeletons or fine pots) receive first-aid conservation treatment and, depending on their progress are then either sent to the Archaeology laboratories or remain in the Conservation laboratory for further treatment. All finds are then classified and the data entered into the Patronato's computer database for future analysis. Although much archaeological material is still waiting to be analysed, a solid reference collection is being formed.

\section{Field Season}

The excavation of the residential area to the west of the Plaza (Mendizábal 1996) revealed the foundations of the stone walls and columns that sustained the upper wooden structure. Also found were the stone floors of the houses, made with river stones (canto rodado) or bricks. These floor deposits were covered by a layer of broken Colonial roof tiles, which we assume were the roof of the houses, which collapsed after their abandonment. Running alongside the houses also lay the remains of the Calle de la Empedrada, a street that ran the length of the town (west to east) into the Plaza, also made of canto rodado. All these Colonial strata lay beneath the modern fills.

One of the most interesting features was a "rubbish dump" found at the back of the house, which contained thousands of fragments of Colonial artefacts, including European and Panamanian majolicas (a tin enamelled ware), coarse earthenware, porcelain and nails. From the typology and percentages of the ceramics found, it was possible to date the dump to the end of the Colonial occupation of the site, probably the last 20 or 30 years before 1671 .

The Cabildo offices were also explored (Brizuela 1996a, 1996b), revealing the remaining patterned stone floors (canto rodado) and the wall and column foundations. A flight of stone steps leading to a now disappeared upper floor was also discovered under modern levels. Upon removal of the steps for restoration, the fill of the structure was revealed, and a rich collection of "sealed" material came to light, possibly from the 1640 's, when the stairway was built, at the time of the last construction phase of the building. On these steps, a thick pocket of ashes was found, pointing to the last days of occupation, when pirates overran the city's defences and probably torched the buildings belonging to the local administration. No evidence of fire has been located so far at the houses across the Plaza. Brizuela also undertook the excavation and restoration of the Calle del Obispo (Bishop's street), to the north of the Plaza, beyond the Casa Terrín. 
Under the floor of one of these houses, on the south side, towards the coast, the stratigraphy changes, the levels being composed of sand instead of clay, In this sand layer and with the help of an underground resistivity survey carried out by a team of physicists from the University of Panamá, we found the first evidence of Precolumbian materials, directly underneath the Colonial strata. Not only did we find ceramics and bone fragments, but a complete primary burial of a woman, with a funerary offering of ceramic vessels, a Spondylus seashell necklace and 9 human skulls (Figure 3 ). As this was an unexpected find, towards the end of the field season (as always happens), and because the emphasis of our excavations was the Colonial period, further explorations into the Precolumbian levels had to be left for the future.

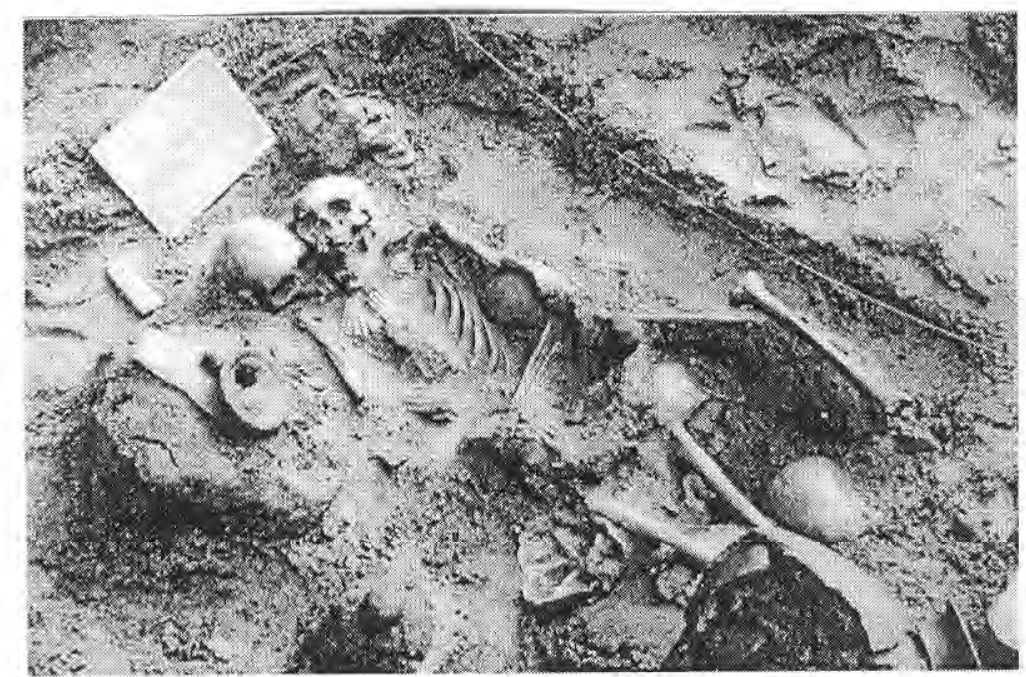

Figure 3 Tomb 1. Precolumbian primary burial of a woman, with funerary offering of ceramic vessels and human skulls. Around her neck, a Spondylus seashell necklace (photograph by T. Mendizábal)

Following the accidental fall of one of the masonry walls of the Hospital de San Juan de Dios, a building outside our current area of research, Brizuela was sent to investigate and to register all the evidence for a possible restoration of this wall (Brizuela 1996a). During his exploration at this site, he was able to dig under the brick floor of the Hospital and find a mass burial, dating to Colonial times. It was a collection of jumbled bones, and we were unable to determine whether they were complete human burials or just parts of bodies thrown under the floor.

\section{Field Season}

The 1997 field season followed the same method as the previous one, this time to the north of the Plaza (Mendizábal 1997). There lay the ruins of the Casa Terrín, a large masonry building that belonged to the Terrín family, from the beginning of the $17^{\text {th }}$ 
century until the destruction of the site. There, the visible remains of this building still standing have been added to and restored throughout this century, with modern cement inclusions and repairs all over the ruins. We excavated almost $50 \%$ of this building, and were able to discover, again, the foundations for the perimeter walls, the arched façade and the support columns, and the walls for internal divisions within the structure. We also recovered the stone and brick floors typical of the era. The brick floor showed evidence of fire, as most of the bricks were stained with soot.

The Casa Terrín proved to be a major source of archaeological materials. Even though most of the floors had barely a few centimetres of topsoil above them, with few materials in them, the fills beneath the Colonial floor levels contained large deposits. Another rubbish dump was found inside the house, over the wall foundations, making it later than the structure itself. From this fill again we recovered thousands of fragments of archaeological materials, such as European and Panamanian majolicas, porcelains, earthenware, animal bones, and metal refuse in the form of nails, door hinges, tacks, pins and coins. Fortunately this deposit did not present much modern intrusion, and we were able to date it through seriation to the beginning of the $17^{\text {th }}$ century; it probably started to be used shortly after the house was completed around 1617 .

In the same house, we found under the foundation of a wall a disused well. The well's rim had been levelled to the ground and the well itself filled up with rubbish. After it was cleared out, it proved to be 6 metres in depth, with a diameter of about 2.5 metres. The fill was comprised mostly of the same materials as the other deposits located in the site: ceramics, bone, metals, etc. We could firmly date the fill to the $16^{\text {th }}$ century, as it was underneath the walls of the Casa Terrín, which was built at the beginning of the $17^{\text {th }}$ century. From it, for the first time, we recovered complete Colonial artefacts, in the form of botijas peruleras, large ceramic containers used to carry different liquids, such as water, wine and olive oil. As they were intact, they presumably had fallen into the well when it was still in use, otherwise they would not have survived the fall.

Although more samples are needed to obtain a broader view, these four contexts found in the 1996-7 seasons (the rubbish fill from the well and Casa Terrín, the fill of the Cabildo stairs, and the rubbish dump in the houses in the Plaza) have helped us trace the changes and continuities in material culture in the Colonial period of the city.

The Casa Terrín received the most thorough post-excavation conservation treatment of all, with some of the modern "restorations" being removed, and the walls and floors treated and/or laid again, to prevent further damage from the elements (Brizuela 1997).

\section{Field Season}

The 1998 field season consisted of a systematic survey of the Plaza itself (Mendizábal 1998). Test pits were dug every 5 metres on a grid set up over the Plaza, the purpose being to find any surviving floor the Plaza might have. Also, because of the Precolumbian burial found in 1996, the survey was also intended to 
probe the Precolumbian levels in the Plaza for more burials and/or materials. Alongside the survey, a removal of all modern additions to the Plaza was carried out. The street, commemorative monuments, park benches and pavements were uprooted to give the Plaza an "unpolluted" look. After the survey was finished, the whole area was topped with grass to prepare it for visitors to the site.

The survey proved that the Plaza did not have any flooring at all during Colonial times. In the middle of the Square we found another rubbish pit, which we have not yet dated. As already observed in the 1996 season, in the southern areas, near the coast, the strata change from clay to sand, and here too we were able to find a number of Precolumbian burials, both primary and secondary, in a good state of preservation (Mendizábal 1998; Brizuela 1998). The primary burials were of individuals in extended or flexed positions with ceramic and lithic work offerings; the secondary ones came in the form of burial urns containing the remains of several persons. The sandy strata where the burials lay are saturated with thousands of fragments of Precolumbian ceramics and mollusc shells, constituting a thick midden of hitherto unknown material.

These Precolumbian materials provide an excellent opportunity to bring a virtually unknown region of our Prehispanic past into current archaeological discussion. Precolumbian Panamá has been divided into three archaeological regions, Western, Central and Eastern (Cooke 1976: 122). Panamá Viejo lies in the border zone between the Eastern and Central Regions, and it is the Eastern Region (comprising the territory between the Colombian border and the Panama Canal approximately) that is the least known archaeologically (Figure 1). At the time of European contact, this area was occupied by a sizeable group of Indians, politically organised into chiefdoms, that shared a linguistic link, in the Cueva language (hence the name "Cueva” Indians). From ethno-historical sources and modern research, it seems that these people had occupied the Eastern Region of Panama for a considerable amount of time, perhaps going back to the beginning of the Christian Era. Several authors have treated this subject before, but the amount of archaeological information available is still scant (Biese 1964; Helms 1979; Drolet 1980; Romoli 1987).

\section{Field Season}

According to Dr. Rovira (pers. comm. 1999), during the current year the systematic survey has been extended to cover the entire site. It follows the same strategy as the Plaza survey in 1998, excavating until culturally sterile levels are reached. This will provide a more accurate picture of the original extent of both the Precolumbian and Colonial occupations.

\section{Panamá Viejo in the Context of Panamanian Cultural Heritage Management}

During the seventies, "suddenly environmental protection became a major international preoccupation” (Cleere 1989: 3), a trend with which Panamá is only now catching up. Part of this concern is the need to preserve cultural heritage, as well as the natural environment. Henry Cleere (1989) succinctly summarises the basis and major issues of Cultural Heritage Management today, issues with which the Patronato Panamá Viejo is also dealing. “Archaeological heritage management has an ideological basis in establishing cultural identity, linked with its educational 
it has an economic basis in tourism and it has an academic function in safeguarding the database" (Cleere 1989; 10).

It is often the case in many developing nations that governments face a myriad of problems to solve (financial crisis, rampant poverty, lack of health and education, etc.). Consequently, the conservation of cultural heritage is seen as a "less important" and sometimes "irrelevant" matter. Panamá is no different in this respect. In Panamá Viejo's case, it is the first time in Panamanian history that the government and the private sector have devoted their attention and resources towards this problem in a serious, committed and seemingly long-lasting manner.

Ideologically, Panamá Viejo is a special case in Panamá, for the ruins of the ancient colonial town have always been powerful symbols for the country. The Cathedral's bell tower is as significant to the people of Panamá, and especially Panamá City, as the Statue of Liberty is for New Yorkers, or Big Ben is for Londoners (Figure 4). Panamá Viejo is the most conspicuous and probably the largest archaeological site in the country, and it is in the centre of modern Panamá City. It is the place many Panamanians think of when asked about archaeology or their country's history, and one that is identified by the ruling white and mestizo population of Panamá as their "roots". As such it presents us with a unique opportunity to reach and educate the public in a broader scale, especially in a country where archaeology is just beginning to draw attention to itself.

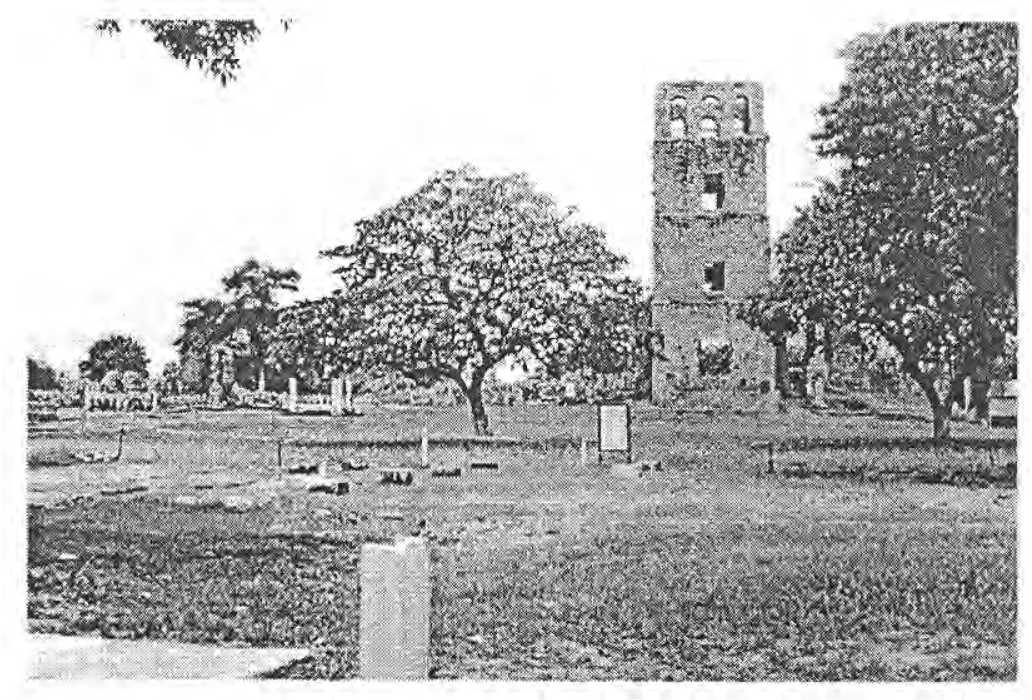

Figure 4 View of the Plaza Mayor in Panamá Viejo, from the west. In the background, the ruins of the cathedral church and its bell tower (photograph by T. Mendizábal)

At the same time, linked with the ideological are the academic concerns. Our 
archaeological project has to face the dilemma of deciding what to conserve, and what to portray to the community, in the face of limited resources and a plethora of evidence from Precolumbian and Colonial times. Originally the project's plan was to excavate the Plaza and its surrounding area, and restore this assemblage (buildings, streets, and Plaza) to show its supposed appearance during the last years of occupation of the site, that is, the time before 1671. As Cleere states, "the debate on the level of restoration and reconstruction that is permissible is an endless one" (1989: 13). The Patronato's conservation architects and archaeologists are following the mandates of the Venice Charter, and are not restoring anything "beyond anastylosis” (idem op. cit.). Nothing is being rebuilt. Currently, only the surviving floors in the last levels of occupation found are being restored and left exposed for the public, while any fragile walls receive conservation treatment, and the modern inclusions are taken away. Therewith, explanatory billboards with theoretical reconstructions, and architectural and historical details are set up in the area around the excavated and restored buildings, as visual aids for tourists. The Patronato has a conservation project (that is beyond the scope of this article) dealing with the stone buildings outside the area of the Plaza and current archaeological excavations. These buildings are being propped up with temporary supports to prevent them from falling apart due to natural (winds, sea waves, exfoliation of the stone blocks) or human (heavy traffic, vandalism) causes, pending a full conservation treatment in the future.

More problematic still is the issue of the Precolumbian remains. The Patronato's main interest is the Colonial phase of occupation, relating to the ideological reasons explained above, and the finding of Precolumbian materials was an unexpected surprise. Since many modern Panamanians of European descent tend to look down on Precolumbian cultures, at times viewing them as "inferior" when compared to the "advanced" Spanish culture, changing current attitudes is a major concern. As the Indians who lived here apparently left no monumental architecture, there is a tendency to perceive them as inferior to their Mesoamerican or central Andean counterparts, who in turn were "obviously" inferior to the Europeans, for even their powerful empires were beaten into submission by a "handful" of brave Spanish knights. This misconception, coming from the fact that western Spanish culture dominates the country, is widespread among many Panamanians and LatinAmericans in general (including some social scientists as well as the lay public), and deserves a serious, extensive debate and reconsideration, to which the Patronato and our research project can positively contribute. This debate could tackle, among others, the issue of "de-colonialization... which includes not only the writing of new histories of the country...by those previously excluded, but also the rewriting of Colonial history to recognise, explicitly, the role of colonialists in disenfranchising from their own pasts the very people for whom they had assumed responsibility" (Ucko 1994: xv). We have an obligation to broaden our limited Western version of history, and "to recognise the various ways of interpreting humanly-created artefacts...” (Ucko 1994: xii), taking into account the views of indigenous cultures that have been pushed almost into extinction. Sadly, surviving Native American cultures are seldom consulted on matters of cultural heritage management 
At present, while most of the Patronato's limited means are being directed towards the conservation and presentation to the public of Colonial buildings and materials,

Precolumbian artefacts are also being dealt with, and the most remarkable finds were recently displayed in a temporary site museum exhibition. The museum exhibits for Colonial and Precolumbian materials have proved to be an excellent tool for reaching the public, especially the thousands of school children who visit the site.

The issues discussed above also involve the educational side of cultural heritage management at Panamá Viejo. Educating the public involves changing current popular views about issues such as the value of Precolumbian cultures or the role of archaeology as a modern science, rather than as a hobby for recovering ancient golden treasure, or sophisticated huaqueria (tomb robbing). For example, when asked about Panamá Viejo, many Panamanians think not only of the aforementioned tower, but also of Henry Morgan, the pirate who sacked the town, and most of all, of the gold the Spaniards are believed to have left buried so it would not fall into the pirates' hands.

At present, the education campaign the Patronato is organising consists of guided site visits, lectures and on-site museum exhibitions, with the latest information from our excavations. Also, wide news-media coverage, with weekly newspaper supplements and occasional television interviews help in our efforts to reach and educate the public. Scientific publications are currently being created.

At the same time, the project is also tied up with the economic concern in Panamá Viejo. Panamá suffers from a high rate of unemployment, and the tourism industry is just starting to develop in our country. As the site becomes an attraction for internal and external tourism, through the Patronato's scientific projects, its creation of public awareness, and its dealings with tourism authorities, Panamá Viejo can generate badly needed dividends that could be reinvested not only in continuing the excavation and the conservation of the site in general, but also in generating jobs in the surrounding community. A very low-income suburb of Panamá City, where unemployment is one of the main problems, surrounds Panamá Viejo. There is a need for site guides, maintenance and gardening crews, security guards, laboratory and field assistants, and other positions that, following training, could be filled by students and the local community. There have also been employment opportunities for scientists as the archaeological project shows.

One of the most significant aims of the project is to set a precedent for the future scientific exploration and management of Panamanian archaeological sites. It must be stressed that this is the first time a project of this magnitude has been undertaken entirely by Panamanian nationals, without any foreign assistance. It is hoped that it will set an example of how archaeological investigation projects should be conducted, with adequate research, treatment and later publication of the findings. Past archaeological projects run entirely by Panamanian hands have generally failed to accomplish this, the information accumulated simply being stored in a museum, sometimes never seen by the public. Poorly conducted excavations, added to a lack of publication means that a considerable amount of data has been lost or is now very 
difficult to access, especially as the few reports that have been published are now outdated. In addition, there have been many foreign expeditions that have just taken artefacts and excavation data out of the country - again, sometimes without any publishing inside or outside Panamá.

There have, of course, been several successful national and international scientific research projects that have added much to the knowledge of Panamanian archaeology, such as those conducted by the Instituto Nacional de Cultura during the seventies and eighties, or the more recent Smithsonian Institution's excavations at Cerro Juan Diaz (Cooke and Sánchez 1997), to name but a few. Nevertheless, Panamanian nationals have never accomplished this before on such a scale.

\section{Conclusion}

The Patronato's work is far from over. At the time of writing, a Master Plan for Panamá Viejo is being drawn up to establish rules that will be used to manage the site in the years to come, planning everything from excavation and conservation to publication of findings. The site is also being prepared to cope with increasing amounts of tourists, by adding security measures and infrastructure so that visitors can comfortably come without harming the ruins. The publication of research results is underway.

The ultimate purpose of the Patronato Panamá Viejo is to mould Panamá Viejo into an archaeological park/research centre, where both the lay and scientific public can enjoy, study and learn about Panamá's diverse history and culture. It is now the duty of Panamanian scientists to give Panamá Viejo its rightful and long overdue place in the eyes of the national and international communities. In a sense it could be said that the Patronato and its multidisciplinary project are the trial by fire of contemporary Panamanian social science, and that Panamá Viejo is its testing ground.

Readers are invited to contact the Patronato at the following address:

Patronato Panamá Viejo

P.O. Box $87-4432$

Panamá 7, Panamá, Rep. of Panamá

Tel. (507) 224-2155

Fax. (507) 224-2157

http://www.patropan.org

patropan@pty.com

\section{References}

Biese, L.P. 1964. The Prehistory of Panama Viejo. Smithsonian Institution, Bureau of American Ethnology Bulletin 191 Anthropological Papers, no. 68.

Brizuela, A. 1996a. Informe Final de Trabajos de Campo en: el Cabildo, San José, Hospital San Juan de Dios y Calle del Obispo. Panamá: Patronato Panamá Viejo.

Brizuela, A. 1996b. Informe Final de Actividades (Restauración): Cabildo, Plaza y 
Calle del Obispo. Panamá: Patronato Panamá Viejo.

Brizuela, A. 1997. Informe Final de Actividades y Restauración en Casas Terrín. Panamá: Patronato Panamá Viejo.

Brizuela, A. 1998. Excavaciones en Casas Oste (... i y la encontramos!...). Informe de actividades mayo-junio. Panamá: Patronato Panamá Viejo.

Cleere, H. 1989. Introduction: the rationale of archaeological heritage management, in Cleere, H. (ed.). Archaeological Heritage Management in the Modern World. London: Unwin Hyman: 3-17.

Cooke, R. 1976. Panamá: Región Central. Vínculos, Revista de Antropología del Museo Nacional de Costa Rica. 2 (1): 122-40

Cooke, R. and Sánchez, L. 1997. Coetaneidad de la metalurgia, artesanías de concha y cerámica pintada en cerro Juan Díaz, Gran Coclé, Panamá. Boletín del Museo del Oro 42

Drolet, R.P. 1980. Cultural Settlement along the Moist Caribbean Slopes of Eastern Panama. Thesis submitted in partial fulfillment of the requirement for the degree of Doctor of Philosophy in Anthropology in the Graduate College of the University of Illinois at Urbana-Champaign.

Helms, M.W. 1979. Ancient Panama: Chiefs in search of power. Austin: University of Texas Press

Mena García, M. 1992. La Ciudad en un Cruce de Caminos (Panamá y sus orígenes urbanos). Sevilla: Escuela de Estudios Hispano-Americanos de Sevilla

Mendizábal, T. 1996. Informe de Excavación: Casas de la Plaza, Temporada de Campo Abril-Septiembre 1996. Panamá: Patronato Panamá Viejo.

Mendizábal, T. 1997. Excavaciones en las Casas Terrín, Enero a Junio de 1997. Panamá: Patronato Panamá Viejo.

Mendizábal, T. 1998. Informe de Labores: Sondeo de la Plaza de Panamá Viejo, Febrero - Junio 1998. Panamá: Patronato Panamá Viejo.

Romoli, K. 1987. Los de la Lengua de Cueva: los Grupos Indígenas del Istmo Oriental en la Epoca de la Conquista Española. Bogota: Instituto Colombiano de Antropologia, Instituto Colombiano de Cultura. Ediciones tercer mundo.

Ucko, P.J. 1994. Foreword. In Stone, P.G. and MacKenzie, R., The Excluded Past: Archaeology in Education. New York: Routledge 